\title{
The Women's Collective Experience of Violence Victim of Military Operation Area in East Aceh
}

\author{
Nurjannah $^{1}$ \\ \{nurjannahfis@unimed.ac.id\} \\ Anthropology Education Study Program, Universitas Negeri Medan, Medan, North Sumatera, \\ Indonesia $^{1}$
}

\begin{abstract}
The experience of women in the period of Military Operation Area (Daerah OperasiMiliter/DOM) implementation in Aceh was a bad experience as a very painful social practice. This is not only felt by victims but also by families who witnessed the suffering. All forms of violence have arisen the attitude of women victims of DOM, namely a sense of same fate, deep physical and mental injury. This is not only experienced personally, but rather becomes a collective experience. This collective experience is a memory of the suffering felt by all women victims of DOM in East Aceh. This is a real form of collective experience between victims of violence. This can be seen in the form of violence categorized in the realm, namely physical, psychological, sexual and economic violence.
\end{abstract}

Keywords: collective experience, military operation area, violation, women

\section{Introduction}

Women are part of society which also participates in all aspects of life including: religion, education, social, legal, political, economic and cultural aspect. All of theseaffect and are affected by women. History notes that Acehnese women have a central role in almost all lines of life. Both as rulers, clerics, fighters, educators and politicians. However, along with the change of time, the progress of Aceh's women has decreased slowly due to the prolonged conflict in Aceh.

As has been known historically, Acehnese women played quite influential roles, giving birth to women who had great works and gait which influenced the continuation of the development of the kingdom of Aceh and in the struggle for the independence of the Republic of Indonesia from the hands of the invaders.

A woman with her life experience during the Military Operations Area was a standpoint that could be analyzed socially. Women's perspectives are considered important and valuable to reveal an incident of violence throughout the conflict in Aceh. The events can be explained in real and what way the female victims are without any political elements and obscure an incident, also about what and how to become Acehnese women. A perspective on the events experienced by women directly about oppression, violence, as well as the massacre of the entire Acehnese people.

The incident of violence in the Military Operations Area (Daerah OperasiMiliter/DOM) from 1989-1998 between the Free Aceh Movement and the Indonesian National Army (TentaraNasional Indonesia / TNI) can be presented objectively as well as partially by women. 
Partially in accordance with the meaning of Harding and Wood (1993) that the standpoint of women or other minority groups will always be partially in accordance with the situated knowledge of women, so as not to give a clear view of the same thing. Therefore the violence that afflicts women varies according to the form of violence and reactions issued by women obtained from their situated knowledge. Subordinate groups such as female victims provide a more complete picture of the world and therefore better than the images given by respectable community groups.

The experience of violence felt by victims makes them condemn the event, even what cannot be forgotten is the actions of the perpetrators. Until now, the feeling of the same fate has become a collective experience (collective memory) of women victims of DOM in East Aceh. Collective experience here is the experience on the depth of violence felt by victims both physically, psychologically, sexually, and economically.

\section{Conceptual Framework}

\subsection{Standpoint Theory Harding}

The feminism movement is not a revenge movement in order to undermine the existence of men in their work to run the social and world system and structure. The feminist movement is purely prioritizing aspects of equality of roles and rights in actualizing oneself as the highest human needs. This equality covers political, economic, cultural, ideological and environmental fields (Nugroho: 2008)

Because the struggle for feminism aims to equalize the social position of men and women, feminism is often considered to reintegrate humanity. This means that considering humanity, men and women are same, and therefore social opportunities should also beequal both for men and for women. Dzuhayatin (2002: 4) expresses the construction of feminism itself is built on the awareness of women's oppression. This awareness makes feminism have the character of 'siding' and not infrequently 'suing'. It does not even close the possibility that feminism's "alignments" towards the fate of women "translated" as a threat to men.

Chafetz (Ritzer, 2012) assumes that women occupy a low position in society, which he calls gender stratification. In families, for example, women (or wives) are in an oppressed position in relation to economic, sexual and property ownership functions, as well as the distribution of inheritance. Problems of injustice and gender inequality in families and communities have led to various reactions from various circles of society. Socio-cultural differences underlying the injustice and gender inequality in various places have long been observed and analyzed into diverse feminist theories.

Patriarchy historically is not only the first structure of the system of domination and subjection, it still continues as a pervasive and lasting system of inequality, a model of basic social domination (Lerner, 1986). Through participation in patriarchy, men learn to defend other humans in humiliation, see them not as humans, and control them. In patriarchy, men see women learn what subordination is (Ritzer, 2012: 805). As the thoughts of Acehnese women are the result of the construction of patriarchal culture that has developed so far in the daily lives of Acehnese women. They are used to the assume that women are normally in the kitchen, wells and mattresses. A stereotype that the author thinks is discriminatory tasting. Because of this kind of thinking, it causes women to assume or 'accustomed' to play only on the domestic side. 
According to Murray and Wendee (2000) the feminist perspective considers that government regulation has to do with government politics and a rigid / formal political system, but is related to human relations in daily life. In feminist studies it is no longer talking about sex and gender issues that are associated with social and political theory. The theory addresses the understanding of governance politics in a capitalist environment and political power in countries with liberal democracies.

\section{$2.2 \quad$ Resilience}

With regard to one's mental attitude to survive in conflict, it can be linked to resilience. Resilience is a manifestation of attitude (trait). This is a hidden capacity that appears to fight individual destruction and protect individuals from all obstacles to life. Individuals who have good intelligence, adaptability, social temparament, and interesting personality ultimately contribute consistently to self-esteem, competence, and the feeling that they are lucky (Benaag 2002: 3).

That is the attitude of the individual who is resilient. Resilience is also called by Wolin \& Wolin as a skill when facing the challenges of life or the capacity of individuals to remain "healthy" and continue to improve themselves. In addition, Benaag (2002: 3) also states that this is a process of interaction between individual factors and the environment. This individual factor serves to withstand self-destruction and make positive self-construction, while environmental factors serve to protect individuals and "soften" the difficulties of individual life.

Resilience is influenced by external factor support and the resources that exist in a person (eg family, institutions that care for women), personal strength that develops in a person (selfesteem, spirituality, self-monitoring ability and helpfulness) and social skills (overcoming conflict, communication skills) (Nuryanti: 2011).

\subsection{Memoria Passionis}

Metz (A.Luluk Widyawan, 2006) reminds us of the importance of remembering memories that have passed including the memory of suffering, misery, and various other troubles. Because this will bring a very positive impact. Not only will people continue to be grateful for the conditions they are living, but also will help them in motivating themselves to continue to reach a better direction.

Furthermore, Metz distinguishes memory into three types. First, memory of the good old days, the past being a harmless paradise and a disappointing escape from the present. Second, clean the past from everything that is dangerous and oppressive. War, for example, is remembered by soldiers as a form of adventure, cruelty that happens and is forgotten. Third, is a dangerous memory, namely the memory of suffering, because the memory that forms is one's identity. Memory loss is known as forgetting to delete identity. Therefore, the memory of suffering demands to be told through storytelling from the victim (Ryadi, 2004: 9).

Meanwhile, Guy (2005) describes that recall is a subject of liberation to work. Selfcontemplation of memory is a kind of "new birth" of acceptance in "being" in a new lifestyle from the side of the dark part of life because the finite cannot escape. Memory as if rediscovering a pillar in his world. Derrida, an expert in measuring memory, does not stop at this memory. This does not mean that he ignores the inevitability of recall, with a form of understanding that is in line with Walter Benjamin. However, more is intended to revive the ruins of the past so that we can become forces that are cut off from a sustainable time. But he 
is more concerned with memory (gedachtnis), though by pointing to differences (Basis, 2005: 54).

Memoria as revealed by Shindunata (1994) is that those who suffer in the past timeare important keywords in modern political theology. This theology views itself as a fundamental theology. The memory of those who suffer is one characteristic of this theology that distinguishes itself from fundamental theology in general. In particular, political theology pays attention to the fate and safety of those who suffer, lose, and become victims in history. It wants to help modern humans realize the importance of memory for its political consciousness. Without that memory, humans will only become like a robot: an intelligent being but without feelings and morals.

The events that happened specifically to Acehnese women were inspiration and memory for their struggle in the present. If for victims who are suffering, persecuted, and oppressed, revealed to the present, then what will happen is what Walter Benjamin calls a "salvation of the past". And this past salvation can only occur in conditions that are possible in the present. Therefore, the understanding of past events through memory, means to understand history as something that has a relationship to a subject who remembers it in the present. If Acehnese women remember their past suffer, then it needs a form of compensation, settlement and even responsibility. Sinceshe ventured to remember her past even though it was full of suffer, but She makes it as a whip for her to survive.

This is in line with the meaning of violence asserted by Galtung (Rupesinghe, 1994), that it is an assault on the physical and psychological mental integrity of a person from various sources. The definition of violence is characterized by physical, biological or spiritual pressures that are directly or indirectly carried out by someone in another person who has exceeded a certain tolerance threshold.

Discussions related to memoria passionis experienced by women victims of violence due to the implementation of DOM in East Aceh, inevitably also discussed gender. Violence originating from gender assumptions or gender related violence is basically caused by violence, both at the family level, and by the state. The position of women is considered weaker than men, so often there is oppression among women during the war.

\section{Method}

\subsection{Research Design}

The method used is a feminist case study research method. This focuses on the analysis of the experiences of selected women groups in various cultures and time periods (Reinharz, 2005: 225). This refers to the opinion of Harding (1993) which explains that in science, the perspective of women in a study is very important to achieve good science. In addition, according to Harding (1993), scientific research in the perspective of feminism requires a stronger objectivity. Harding saw that objectivity in every research that had been applied so far had not been tight enough.

Research on feminist case study of DOM victim is closely related to how research subjects interpret the events they experienced. Therefore, social realities that occur in the field must be obtained through an observation that can describe how women victims of this poverty can tell about their suffering during violence. Of course, the writer must appear, not only able to describe the phenomena that exist through thinking or just reviewing through various 
literature. The researcher is here as a person who sees women who are the subject of research. In this case women are victims of DOM violence in East Aceh.

\subsection{Research Location}

In relation to the violence that occurred and the location of DOM, the research was mapped based on the target village typology. The first typology is villages that often suffer from DOM violence; the second typology is that the community lives in a traumatic situation, especially women who suffer from DOM violence; third typology, a village that has a history of violence and has many women victims of DOM violence. From the total typology, the most suitable area to become a research center is in East Aceh, precisely in the District of Idi Rayeuk, Rantau Peureulak, Peureulak Timur, Langsa, and EastBirem Bayeun.

\subsection{Informants}

The informant in this paper is all Acehnese women who experienced violence due to the implementation of the DOM status in Aceh. Women who were selected as informants were them who had been arrested, experienced violence, both physically and psychologically, losing family members directly or indirectly, humiliation, until they were traumatized. In addition, community leaders are spread in a number of areas in East Aceh.

\subsection{Data Collection}

The data collection process is carried out by utilizing several data collection techniques commonly used in feminist case study research, namely observation, in-depth interviews, document studies, and documentation.

\subsection{Data Analysis}

Life history analysis technique is used in this study to analyze data obtained in the field. This technique is important to know the things experienced by the resource person, in this case the women victims of DOM violence in Aceh, in accordance with the purpose of the study, namely to obtain in-depth understanding and answers through qualitative analysis related to the experiences of women victims of DOM and efforts to maintain self-survival and his family.

This analysis can be used to see the actions, reactions, interpretations, and views of life of women victims of violence in Aceh today. This is to understand how the experiences of women victims of DOM are created, as well as their influence in terms of the point of feminism, their impact, and the survival strategies applied in life at this time.

\section{Results And Discussion}

\subsection{Collective Experience of Violence on Women Victims of DOM Enforcement in East Aceh}


The experience experienced by women during the DOM implementation in Aceh was a bad experience as a very painful social practice, not only for the victim but also for the family who witnessed it. The experience received is not only in a Personal Experience, but rather a collective Experience. Not only social experience, as described by Kuntowidjojo (1991) which leads to the entire Acehnese society, collective experience is a memory of the suffering felt by all women victims of DOM in East Aceh.

Although it is difficult to know the exact number of human rights violations committed by the military on women, but the results of the FPHAM investigation in Aceh from 30 July. $d 13$ November 1998, there were 7227 cases of violations consisting of 1321 people dead, 1958 missing, 3430 people were tortured, 128 raped, 81 were sexually abused, and 38 motorbikes were looted.

Moreover, in the prolonged conflict in Aceh it was women who suffered the most. The reason is that various acts of violence against women are constantly felt and experienced by women in Aceh (Pane, 2001: 272). Feelings of mutual affinity make Acehnese women must rise from the downturn of their lives. From the data compiled, Pane explained, during the period from January to May 16, 2001, in the three conflict centers, North Aceh, East Aceh and Bireuen, 20 women were victims of violence. Seven of them died. This number is of course even more, if the entire area of Aceh is recorded. Because, there are victims who live in the interior, if killed by violence directly buried their families without being taken to the hospital for divisum. This was done because most of the people of Aceh believed that there was nothing. In addition, many injured victims then died as a result of not getting proper treatment because the victims' families were hindered by financial conditions in the form of inadequate costs.

These various cases of violence certainly made the disappointment to women, powerlessness against the system, and unpreparedness to accept conditions. Then, it made some of them psychologically disturbed. Extraordinary violence has tarnished Aceh's women's dignity for years due to the cruel acts of the TNI. They were disappointed with many parties, ranging from the government, military / police officers, Free Aceh Movements, local government and Acehnese figures who just kept quiet seeing the endless conflict.

With various advocacy and forms of popular demand to revoke the status of DOM conducted in Aceh, the TNI still diligently entered the village, established posts, and conducted strict patrols Intimidation and violence carried out by conflicting parties make citizens in an uncomfortable situation. The pattern of spreading fear to citizens and the hallucination of security forces often makes citizens a target of violence, which creates an atmosphere of fear among citizens.

On the other hand, not a few of the local residents who became free Aceh movement activists, whether they were active in guerrilla and entered the forests, or who remained ordinary villagers but in fact he was a communication officers who had the function of collecting and providing information to free Aceh movement soldiers. This can be triggered by several things, the first is because of the desire to achieve the independent of Aceh. The second thing is because he had seen his family, relatives, including husband, wife and children, murdered viciously in front of them. Of course, there is a form of inner turmoil to take revenge on the perpetrators. To fight personally, surely he will not be able to. Therefore, guerrilla entry into part of the free Aceh movement is the only way to fight the perpetrators of the killings.

As it turned out, the army seemed not to want to run out of members, they were vigorously carrying out doctrination and coercion of Acehnese youths to enter into part of Unit Ksatria Penegak Pancasila (UKPP). The people were forced to become ABRI members 
through UKPP since 1991. Coercion was filed so that they were according to the TNI's will. The goal is not to become part of GPK / GAM. Even though the people are more calm planting, farming in their fields and fields. All day they have to practice. Indeed, they were paid by TNI, but they did not like the job at all.

In each village in DOM, the army formed militias which inevitably increased the scale of violence and human rights violations. In the words of the local military commander, young people are always considered to be the spearhead who is considered very aware of who is a member of the GPK. Refusal to be involved in TNI militia organizations or failure to demonstrate a strong enough commitment to quell the enemy by identifying, arresting and killing suspected rebels, sometimes made them get punishment from by TNI, in the form of being arrested, mistreatment and torture.

Through various efforts to free themselves from adversity, the women victims of DOM carried out various forms of application, ranging from complaints to local law help association, student organizations, local governments, to the Indonesian Parliament. Various Acehnese students both inside and outside Aceh are constantly looking for ways to end this long conflict. One of them is through dialogue channels, such as seminars involving various groups.

All forms of violence have led to the attitude of women victims of DOM, namely a sense of same fate and resentment or hurt by the central government's treatment of them. This is a tangible form of collective experience which was only the experience of individual victims of violence. This can be seen with the form of violence categorized in four (4) domains, namely physical, psychological and sexual violence; lost husband; arrest, search, burning of property, and terror; and torture and imprisonment.

Collective experience becomes a story of Aceh's dark history when talking about women and conflict. There have been various scientific writings that have voiced injustice that occurred to the people of Aceh, especially the women. This inevitably led to the presence of Acehnese women in the conflict as an inong balee force. The formation and presence of the Inoeng Balee troops (Widowed women) indirectly is a form of mutual commitment that is in the souls of Widow women whose husbands are tortured, even killed by the TNI. They also carry arms in order to uphold something they consider to be honorable and to revive the dignity of Acehnese women through the values of the struggle and the upholding of Islam.

The parties who have common interests and interests differ from one main issue, then reconstruct the thoughts, steps and actions of violence (conflict). In other words, ethnic conflict and communal conflict is a social dynamic as a whole, where mass groups and elites have the same contribution in the conflict, behind every conflict there must be a "master mind" (provocateurs), who utilize the condition of the community so that it impacts conflict.

\subsection{Impact of Violence Experienced by Women Victims of DOM Enforcement in East Aceh}

Conflict is not a strange thing in human life. Throughout life, humans will always be faced with conflict. Almost impossible, conflict can disappear on this earth, both individually and in groups. The Aceh conflict period which broke out since 1976 is one example that conflict will always occur, especially when group expectations are not in accordance with reality.

As the conflict in Aceh began when free Aceh movement's pioneer, Hasan Tiro proclaimed the this movement on December 4, 1976. This conflict did not end just like that, but like a coal in the husk continued and peaked during the DOM status. Even after the 
revocation and enactment of Civil and Military Emergency, Aceh became a very gripping region.

The conflict in Aceh is a form of disagreement between two or more members of an organization or group within an organization that arises because of having different status, goals, values and perceptions. The impacts arising from conflict can become functional conflicts and infective conflicts. Conflict is said to be functional if the impact can provide benefits or benefits for the organization, on the contrary it is called infunctional if the impact is actually detrimental to the organization. The conflict in Aceh is a form of infective conflict that is very detrimental to all parties, not only free Aceh movement and the TNI, but also the Acehnese women who felt suffering throughout the conflict, even today.

Repressive violence by the state apparatus is closely related to the revocation of basic rights to survive and to be protected from pain and suffering by the state. Repressive violence is related to three basic human rights, namely civil rights, political rights and social rights. Social rights are related to freedom of thought, religion, freedom, organization and privacy equality before the law. Political rights relate to democratic rights to participate in political life such as participating in elections and freedom of speech and opinion. While social rights are related to the prohibition to create or have a trade union or prohibition to strike.

In addition to repressive violence, there is also alienative violence that refers to the revocation of higher individual rights, such as the right to psychological (emotional), cultural or intellectual growth (rights to emotional, cultural or intellectual growth). The importance of incorporating human rights into this type of alienative violence is to assert that humans also need to fulfill non-material needs, job satisfaction, engage in creative activities, children's needs for affection, a sense of social ownership or cultural identity.

One of the most violent forms of alienative violence is what is called ethnic cleansing (ethnocide), which is a policy or action that actually changes material or social conditions under one of the dominant cultural identities of a particular group. This violence also indirectly, grounded thousands of ethnic Acehnese for the domination of the IndonesianJavanese rulers.

In the end, the prolonged conflict that occurred in Aceh, from 1989-2004, has given rise to various incidents of violence against women such as abuse, sexual harassment, rape and murder which cause deep hurt to Aceh women. Victims of conflict that affect Acehnese women are generally experienced by every woman, especially in the east Aceh area. Ranging from children, adolescents, to adult women (married) became victims of violence. For 12year-olds, there were those who did not continue their education to a higher level because they were afraid of frequent gunfire between the TNI and the free Aceh movement members. Viewed from adult women, most of the Acehnese women as victims of conflict now bear widow status because their husbands died during the conflict.

Acehnese women who bear the status of widows must carry out their lives by supporting their children to become dependents while educating and guiding them to become adults who are useful for religion, and the nation. Awkwardness must occur where usually this is a joint responsibility with the husband to make a living and educate their children. This condition then worries the hearts and minds of Acehnese women who are victims of conflict (especially widows who have children). Even though the psychology of the mother alone is not necessarily able to guide her to get out of the experience. Data on the field shows that it is the child who revives the spirit of their mother's life. They take care of their mothers when they still feel pain, even providing for the remaining fields. So that it is not only the mother (widow) who must make a living, but also the child (both male and female) who acts as breadwinner when their mother is still in an unstable state. 
In addition, due to the low level of education, most women victims work as farm laborers. Because lack of education, it causes difficulties in getting a better job. Based on the work pursued by Acehnese women both during the conflict period of the DOM and post-conflict, the average of them have a job as a farm laborer. In addition, this is because they do not have their own land to grow crops during the planting season (rice in the fields). They often work in neighboring fields that have a piece of land, and some of them also go to the fields of the other sub-districts where the distance is tens of kilometers. Generally, the harvest is divided into two between farm laborers and farmers' land used.

\subsection{Aceh's Hikayah as Motivation to Revive}

The Acehnese rose to defend their property. The Aceh War broke out from 1873 to 1914. The Dutch suffered many financial losses and the lives of their soldiers. All of this was due to the development of the myth of the Hikayah of Sabil War, which always encouraged Acehnese people to oppose oppression. This was able to motivate the Acehnese because there was a "guarantee of heaven" to the people who did jihadi fisabilillahor struggle in His way. Here is the poem of the hikayah: Who is willing to give up life and property / For the cost of war in the way of the Divine / Allah bought it in high price / High heaven as the exchange is certain. Not only in the form of hikayah, this is also socialized to children since childhood through singing before going to sleep.

The song lyrics lull Aceh children as follows:

"Dododaida, bunga mekar dalam istana.

Cepatlah besar muda belia.

Membantu perang tolong Negara.

Cepatlah besar muda belia.

Membantu perang bela agama.

Perang hai perang dijalan Allah (Sabilillah).

Syahid dalam perang, perang Sabilillah.

Jika syahid anak dalam perang,

Ridha Tuhan permata hati."

This hikayah and song show that if the people of Aceh are constantly pressured by various violence, they are not reluctant to fight with violence as well and this has been taught by parents since childhood. The impact of this civilization is Aceh's long-standing conflict with the center. Amien Rais said that the actions of TNI in Aceh were acts of genocide, the extraordinary elimination of humans. Therefore, both the government and TNI directly, must dismantle the mass graves of the DOM victims, then bury them again in Islam. For writer, this concept is more about ethnocide, namely the massive elimination of humans in one type of ethnicity, that is Acehnese.

InTNI's side, they are responsible for the killing of Acehnese during the DOM period and it would be dealt with, so it will not cause a burning grudge among the people of Aceh. But unfortunately, it did not occur. The law in this country clearly looks downward, but blunt upward. The lower middle class society must feel the injustice of the law in force in the Republic of Indonesia. Whereas in the realm of the apparatus, they prefer action with violence in the field, so that mass graves appear rather than bring the victims to court. A normative form of positivistic law in the country of Indonesia, that every guilty person must be tried, not 
arbitrarily killed. One of the most recent mass graves was mass graves after the massacre of Tengku Bantaqiah and his followers in West Aceh.

\section{Conclusion}

For victims, the collective experience related to the violence that was experienced during the DOM implementation in Aceh, will not disappear at any time. Like the wound, he felt for life, every time they feel pain, his memory of suffering in the conflict period is repeated. This may be a threat to the psychology of victims when they have to face the turmoil of life and even physical violence again in this time. Symptoms of psychiatric disorders always accompany the remnants of the lives of the victims, and that potential will always surround the scope of their lives. Family, determination, and proximity to the Divine is the one who is able to direct him to stay positive and work in life.

\section{References}

[1] Chafetz, Saltzman, J.: The Gender Division of Labour and Reproduction of Female Disadvantage: Toward an Integrated Theoy, dalam R.L.Blumberg (ed), Gender, Family and Economy: The Triple Overlap (1991)

[2] Dzuhayatin, dkk.: Rekonstruksi Metodologis Wacana Kesetaraan Gender dalam Islam (2002)

[3] Galtung, Johan.: Kekerasan Kultural dalam Wacana Kekerasan dalam Masyarakat Transisi. Yogyakarta: Insist, Edisi IX. pp. 11 (2002)

[4] Harding, Sandra.: "Rethinking Standpoint Epistemology: 'What Is Strong Objectivity'?" (1993)

[5] Kuntowijoyo.: Metodologi Sejarah (2003)

[6] Nugroho, Riant.: Gender dan Strategi, Pengarus Utamanya di Indonesia (2008)

[7] Nuryanti, Reni..: Perempuan berselimut Konflik (2011)

[8] Pane, Neta S.: Sejarah Dan KekuatanGerakan Aceh Merdeka Solusi, Harapan, Dan Impian (2001)

[9] Ritzer, George.: Teori Sosiologi (Edisi Kedelapan 2012) (2012) 